\title{
Pengaruh Terpaan Media dan Kredibilitas Tuan Rumah (Host) Terhadap Minat Politik Generasi Z
}

\author{
Chaerun N. Damayanti ${ }^{1}$, Amri Dunan $^{2}, \operatorname{Karman}^{2 *}$ \\ ${ }^{1}$ Program Studi Ilmu Komunikasi, Fakultas Ilmu Komunikasi, Universitas Guna Darma, Depok, Indonesia, 16424 \\ ${ }^{2}$ Kementerian Komunikasi dan Informatika, Jl. Medan Merdeka Barat No. 8, Jakarta-Indonesia, 10110 \\ *Email Korespondensi: karman@kominfo.com
}

Kata kunci: Terpaan media Kredibilitas Minat Generasi Z

Keywords: Media exposure Credibility Intention Generation-Z

\begin{abstract}
A B S T R A K
Penelitian ini bertujuan untuk mengetahui bagaimana pengaruh terpaan video Youtube Mata Najwa: Ujian Reformasi dan kredibilitas Najwa Shihab terhadap minat berpolitik generasi Z dalam isu RUU 2019. Penelitian menggunakan metode penelitian kuantitatif dengan menyebarkan kuesioner melalui googledocs. Teori acuan penelitian ini adalah teori uses and gratifications dan kredibilitas sumber dan penentuan ukuran sampel menggunakan rumus Taro Yamane berdasarkan tingkat kesalahan 5\% sehingga didapat sebanyak 400 responden. Pengambilan sampel menggunakan teknik probability sampling. Metode analisis data dalam penelitian ini menggunakan uji validitas, reliabilitas, asumsi klasik, analisis regresi berganda, hipotesis, uji T, uji F dan korelasi koefisien determinasi. Berdasarkan hasil dari analisis data, dapat diketahui bahwa terpaan yang diberikan oleh video Youtube Mata Najwa: Ujian Reformasi dan kredibilitas Najwa Shihab berpengaruh positif dan mempunyai hubungan yang erat dalam menimbulkan minat berpolitik generasi Z dalam isu RUU 2019.
\end{abstract}

\section{A B S T R A C T}

This study aims to examining how the exposure of the Mata Najwa: Ujian Reformasi YouTube video and the credibility of Najwa Shihab on generation Z's political interest in the issue of the 2019's draft law. Researchers used a quantitative research method by distributing questionnaires through google docs. The reference theory of this research is the theory of uses and gratifications and source credibility and the determination of the sample size using the Taro Yamane formula based on an error rate of 5\% so that 400 respondents were obtained. Sampling using probability sampling techniques. Methods of data analysis in this study using validity, reliability, classical assumptions, multiple regression analysis, hypothesis, $T$ test, $F$ test and correlation coefficient of determination. Based on the results of data analysis, it can be seen that the exposure given by the Mata Najwa: Ujian Reformasi Youtube video and Najwa Shihab's credibility have a positive effect and have a close relationship in generating generation $Z$ political interest in the issue of the 2019's draft law.

\section{PENDAHULUAN}

Minat merupakan dorongan dari dalam diri yang memengaruhi kehendak terhadap sesuatu yang merupakan dorongan kuat seseorang untuk melakukan segala sesuatu demi mewujudkan pencapaian tujuan dan cita-cita yang menjadi keinginannya. Minat memiliki unsur-unsur antara lain yaitu timbulnya perasaan, keingintahuan, perhatian, kesiapan bertindak dan kecenderungan untuk terlibat (Shaleh \& Abdul, 2004). Minat merupakan dorongan dari dalam diri yang memengaruhi gerak dan kehendak terhadap sesuatu yang merupakan dorongan kuat seseorang untuk melakukan segala sesuatu demi mewujudkan pencapaian tujuan dan cita-cita yang menjadi keinginannya. Minat memiliki unsur-unsur antara lain yaitu: Perasaan, Keingintahuan, Perhatian, Kesiapan bertindak dan kecenderungan untuk terlibat (Abdul Rahman Shaleh dan Abdul Muhbib Wahab, 2004).

Berdasarkan pengertian tersebut minat berpolitik berarti seorang individu melimpahkan perasaan, keingintahuan, perhatian serta memiliki kecenderungan untuk terlibat atau ikut berpartisipasi dalam hal dan situasi politik di 
Indonesia.Termasuk keinginan untuk mengetahui apa yang terjadi di sekitar mereka.

Politik menjadi hal yang menjadi daya tarik bagi masyarakat. Berdasarkan regulasi di Indonesia, mereka yang memiliki hak untuk memilih dan dipilih dalam jabatan politik adalah mereka yang berusia 17 (tujuh belas) tahun atau sudah/pernah kawin pada hari pemungutan suara. Dalam rentang usia tersebut, mereka adalah generasi Z. Mereka adalah individu antara 1996 2010 (Seemiller \& Grace, 2017). Artinya generasi $\mathrm{Z}$ memiliki hak politik.

Tak hanya pada waktu pemilihan kepemimpinan saja, para remaja juga dituntut untuk memberikan partisipasinya pada kejadiankejadian tertentu yang nantinya akan berdampak pada sistem politik di Indonesia.

Generasi Z memiliki minat politik ditunjukkan dengan keingintahuan, perhatian serta memiliki kecenderungan untuk terlibat dalam politik. Minat politik generasi $\mathrm{Z}$ ini antara lain dipenuhi melalui media komunikasi, termasuk media komunikasi baru. Media yang menyampaikan informasi politik ke masyarakat berperan besar dalam ikut membantu meningkatkan minat partisipasi berpolitik generasi muda baik itu informasi yang positif maupun negatif. Salah satunya media tersebut adalah Youtube. Sejak dirilis pada tahun 2005, Banyak acara TV yang mengunggah tayangannya ke Youtube sehingga acaranya tetap ditonton dan mendapatkan penghasilan lebih dari Youtube. Salah satu acara TV yang kemudian diunggah kembali ke Youtube adalah acara "Mata Najwa".

Acara yang tayang setiap hari rabu pukul 20.00-21.00 WIB itu mengunggah kembali tayangannya ke Channel Youtube pribadi Najwa Shihab di hari yang sama atau sehari setelah tayang di Trans7. Dengan konsistensinya menayangkan isu-isu terhangat seputar kenegaraan.

Salah satu isu yang menarik dan ditayangkan pada saluran Mata Najwa adalah aksi penolakan masyarakat terhadap Rancangan Undang-Undang pada akhir September 2020. Pro dan kontra mengenai pengesahan rancangan Undang-Undang ini dijadikan satu episode tersendiri yang diberi judul "Ujian Reformasi (Shihab, 2020).

Pada episode ini, pihak Mata Najwa menampilkan dua pihak: perwakilan pejabat yang mendukung pengesahan Rancangan UndangUndang tersebut dan pihak yang menolak pengesahan Rancangan Undang-Undang. Perwakilan kubu pejabat yang dihadiri oleh Fahri Hamzah selaku Wakil Ketua DPR, Moeldoko sebagai Kepala Staf Kepresidenan, Asrul Sani Anggota Komisi III, Edward Os Hiariej sebagai Tim Ahli Perumusan RKUHP atau yang mendukung pengesahan RUU. Dan tidak ketinggalan, pihak yang menolak disahkannya Rancangan Undang-Undang tersebut. Mereka adalah: perwakilan mahasiswa yang menjalankan aksi penolakan di depan gedung Dewan Perwakilan Rakyat (DPR), Presiden Badan Eksekutif Mahasiswa Universitas Gajah Mada, dan Presiden Keluarga Mahasiswa Institut Teknologi Bandung, Lembaga Penegakan Hak Asasi Manusia serta kalangan akademisi, dan aktivis Yayasan Lembaga Bantuan Hukum Indonesia.

Tayangan ini menerpa generasi $\mathrm{Z}$ yang memiliki keingintahuan dalam hal politik. Bentuk terpaan ini terwujud dalam bentuk kegiatan mereka untuk mendengar, melihat, dan membaca pesan, mempunyai perhatian terhadap pesan tersebut yang dapat terjadi pada individu atau kelompok. Aspek terpaan media ini mencakup frekuensi mereka dalam menggunakan media, durasi penggunaan media atau berapa lama khalayak menonton sebuah berita dan yang terakhir adalah atensi atau seberapa fokus khalayak menonton berita (Ardianto \& Erdinaya, 2007).

Minat dalam hal politik generasi $\mathrm{Z}$ tentu tidak hanya karena faktor terpaan media yang dalam konteks ini media Youtube melainkan juga karena faktor kredibilitas dari tuan rumah acara. Dalam hal ini, kredibilitas pembawa acara "Najwa Shihab". Apakah pembawa acara 
menimbulkan minat generasi $\mathrm{Z}$ dalam politik di Indonesia. Dalam konteks ini, politik yang dimaksud adalah proses legislasi UndangUndang yang sedang dibahas oleh Pemerintah.

Ada beberapa komponen yang dapat menimbulkan kredibilitas, antara lain keahlian, kepercayaan, dan memiliki daya tarik (Rakhmat, 2012). Dengan adanya terpaan acara "Mata Najwa" dengan tema "Ujian Reformasi" yang bisa diputar berulang kali di Youtube pribadi Najwa Shihab, dan kredibilitas seorang jurnalis senior Najwa Shihab sebagai pembawa acaranya, mungkinkah episode ini mampu menumbuhkan minat berpolitik generasi $\mathrm{Z}$ khususnya yang berumur 17 hingga 24 tahun dalam isu RUU 2019 ?

Ada dua konsep yang dipakai dalam tulisan ini yaitu teori Uses and Gratification. Teori ini awal pertama kali diperkenalkan oleh Blumler (Katz, Blumler, \& Gurevitch, 1974). Teori kedua yang penulis gunakan adalah Source Credibility Theory. Teori yang dulu diperkenalkan oleh Hovland tahun 1953.

Uses and Gratifications memberikan kekuasaan pada khalayak untuk memutuskan media mana yang akan dipilih atau dikonsumsi. Khalayak memiliki peran aktif dalam melakukan interpretasi dan mengintegrasikan media ke dalam kehidupannya. Pada Uses and Gratifications Theory, khalayak akan bertanggung jawab terhadap pemilihan media untuk memenuhi kebutuhannya.

Khalayak yang aktif dalam pendekatan Uses and Gratifications adalah aktif dalam menggunakan media. Mereka menggunakan media karena motivasi tertentu dalam mengonsumsi isi media dan mereka menggunakan media karena proses yang selektif.

Motivasi dalam menggunakan media adalah karena khalayak didorong keinginan untuk memenuhi kebutuhan akan informasi. Mereka ingin meningkatkan pengetahuan mereka serta keinginan untuk mengekspresikan sisi pribadi mereka. Motif sosial mereka dalam menggunakan media adalah motivasi untuk melakukan interaksi sosial dan ingin mencari kesenangan dengan mencari isi media yang memberikan hiburan (McQuail, 2010).

Teori Source Credibility Theory dipakai untuk memberikan penjelasan terhadap kredibilitas nara sumber atau tuan rumah Mata Najwa. Asumsi teori ini adalah orang akan mudah mendapat pengaruh dari orang yang dianggap memiliki kredibilitas. Seseorang akan memiliki kepercayaan dan mendapat pengaruh dari pesan-pesan yang disampaikan oleh mereka yang dianggap memiliki kredibilitas.

Sumber dengan kredibilitas tinggi memiliki dampak besar terhadap opini khalayak daripada sumber dengan kredibilitas rendah. Sedangkan sumber yang memiliki kredibilitas tinggi lebih banyak menghasilkan perubahan sikap dibandingkan dengan sumber yang memiliki kredibilitas rendah (Hovland, 1953) yang kemudian menjadi landasan teori penelitian ini.

Untuk mengukur seberapa besar pengaruh kredibilitas Najwa Shihab sebagai pembawa acara dalam menimbulkan minat penonton, peneliti menjadikan komponen kredibilitas sebagai acuan dalam melakukan penelitian ini. Komponen kredibilitas meliputi: keahlian, kepercayaan, dan daya tarik.

Keahlian adalah kesan yang dibentuk komunikator tentang kemampuan komunikator dalam hubungannya dengan topik yang dibicarakan. Keahlian komunikator berkaitan dengan penilaian komunikan mengenai kemampuan komunikator dalam menyampaikan pesan dan penguasaannya terhadap materi yang ia sampaikan.

Kepercayaan adalah kesan khalayak tentang komunikator berkaitan dengan watak atau kepribadiannya. Komunikator yang dapat dipercaya adalah komunikator yang dianggap jujur, tulus, bermoral, adil, sopan atau etis. Jika khalayak menilai bahwa tindakan atau ucapan sumber didasari motif untuk mengambil keuntungan sepihak, maka ia akan menjadi kurang persuasif ketimbang sumber yang dipersuasi tidak memiliki kepentingan pribadi. 
Daya tarik dapat menentukan efektivitas persuasi yang dilakukan oleh komunikator. Daya tarik komunikator bersifat fisik dan psikis (adanya kesamaan, sudah dikenal, dan kesukaan. Kesamaan dimaksud mencakup kesamaan pada aspek demografi, bahasa, agama, daerah asal, maupun ideologi. Kredibilitas juga bisa bersumber karena kepiawaian komunikator sudah dikenal.

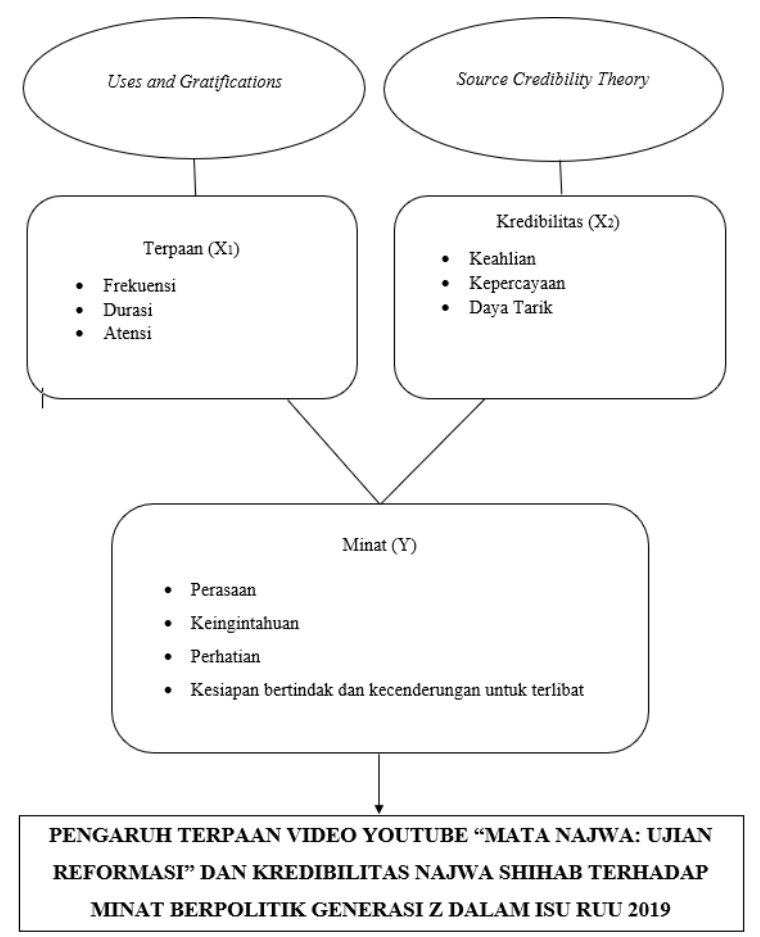

Gambar 1. Kerangka Teori Penelitian Sumber : Dokumentasi dan Pengolahan Data Peneliti (2020)

Hal inilah yang melatarbelakangi penulis untuk meneliti lebih dalam apakah terdapat pengaruh terpaan dari Youtube Najwa Shihab dalam episode "Mata Najwa: Ujian Reformasi" dan kredibilitas seorang Najwa Shihab sebagai pembawa acara terhadap minat berpolitik generasi Z (kelahiran tahun 1996 - 2010) dalam isu RUU 2019.

\section{METODE PENELITIAN}

Penelitian dilakukan pada bulan Maret hingga Agustus 2020 dengan menggunakan pendekatan kuantitatif, paradigma positivistik. Pendekatan ini memiliki orientasi untuk melakukan generalisasi ke level populasi (Kriyantono, 2016).

Populasi dalam penelitian ini adalah viewers dari ketujuh video tersebut yang jika ditotal berjumlah 42,3 juta dan kemudian dihitung rata-ratanya menjadi 6.042 .857 viewers per 24 Maret 2020. Berdasarkan populasi yang tersedia pula, peneliti menggunakan rumus Taro Yamane untuk menghitung jumlah sampel yang akan diteliti, yang diambil sebagai sumber data dan dapat mewakili seluruh populasi (Suharsimi, 2006). Maka dari itu kriteria responden lebih dispesifikkan sebagai seseorang yang menonton video Youtube Mata Najwa: Ujian Reformasi dan termasuk ke dalam Generasi Z yang berusia 17 hingga 24 tahun.

Metode yang digunakan dalam penelitian ini adalah metode survei. Metode survei adalah metode riset yang menggunakan kuesioner sebagai instrumen pengumpulan datanya. Tujuannya untuk memperoleh informasi tentang sejumlah responden yang dianggap mewakili populasi. Peneliti membuat kuesioner dan menyebarkannya kepada 400 responden. jumlah pernyataan pada variabel X1 (Terpaan) sebanyak 12 buah, pernyataan pada variabel $\mathrm{X} 2$ (Kredibilitas) sebanyak 19 buah dan variabel Y (Minat) sebanyak 14 buah ini menggunakan skala likert (Sugiyono, 2012).

Skala pengukuran yang digunakan dalam penelitian ini menggunakan skala likert dengan 4 kategori jawaban yang diberi skor sebagai berikut: 1 (sangat tidak setuju), 2 (tidak setuju), 3 (setuju) dan 4 (sangat setuju). Setelah terkumpul 400 responden, penulis melakukan pengolahan data yang terdiri dari beberapa pengujian di antaranya: uji validitas, reliabilitas, asumsi klasik (uji normalitas, auto korelasi, multi kolenieritas dan heteroskedastisitas), analisis regresi linear berganda, hipotesis, uji $\mathrm{T}$, uji $\mathrm{F}$ dan Korelasi dan Koefisien Determinasi.

Menurut Kriyantono (2016), Uji validitas digunakan untuk mengetahui kelayakan butirbutir dalam suatu daftar pertanyaan atau pernyataan dalam mendefinisikan suatu variabel. 
Suatu instrumen dinyatakan valid jika $R$ hitung lebih besar dari $\mathrm{R}$ tabel ( $\mathrm{R}$ hitung $>\mathrm{R}$ tabel). Sedangkan reliabilitas artinya memiliki sifat dapat dipercaya. Dengan kata lain, suatu alat ukur memiliki reliabilitas bila hasil pengukurannya relatif konsisten apabila alat ukur tersebut digunakan berulang kali oleh peneliti yang sama atau peneliti lainnya. Reliabilitas dinyatakan dengan koefisien reliabilitas yang angkanya berada dalam rentang 0 sampai 1,00. Semakin tinggi angka koefisien reliabilitas atau mendekati angka 1,00 berarti semakin tinggi reliabilitas begitu pun sebaliknya (Kriyantono, 2016).

Analisis regresi linear berganda digunakan untuk menganalisis pengaruh beberapa variabel bebas atau independen variabel Terpaan (X1) dan Kredibilitas (X2) terhadap satu variabel tidak bebas atau dependen variabel Minat (Y) secara bersamaan. Uji hipotesis dilakukan dengan cara membandingkan besarnya angka taraf signifikasi (sig) penelitian dengan taraf signifikasi 0,05 atau $5 \%$.

Jika angka signifikasi penelitian $<0,05$, maka Ho3 ditolak dan Ha3 diterima (Adanya pengaruh Terpaan Video Youtube Mata Najwa Ujian Reformasi dan Kredibilitas Najwa Shihab Terhadap Minat Berpolitik Generasi Z. Uji T bertujuan untuk mengetahui ada atau tidaknya pengaruh parsial (sendiri) yang diberikan variabel bebas (X1) dan (X2) terhadap variabel terikat (Y). Jika nilai signifikansi $\langle 0,05$, atau t hitung $>$ $\mathrm{t}$ tabel maka terdapat pengaruh variabel $\mathrm{X}$ terhadap variabel Y. Sedangkan Uji F digunakan untuk menguji pengaruh variabel bebas (X) secara simultan (bersama) terhadap variabel terikat (Y). Apabila $\mathrm{F}$ hitung $>\mathrm{F}$ tabel maka terdapat pengaruh variabel $\mathrm{X}$ terhadap variabel Y.

Koefisien korelasi merupakan besar kecilnya hubungan antara dua variabel yang di nyatakan dalam bilangan yang disebut dengan Koefisien Korelasi. Koefisien Korelasi di simbolkan dengan huruf R. Apabila besarnya korelasi adalah -1 maka ia dinyatakan korelasi negatif sempurna artinya terdapat hubungan 2 atau lebih variabel namun arahnya terbalik atau saling berlawanan, sedangkan jika koefisiennya 0 maka dianggap tidak terdapat hubungan antara dua variabel atau lebih dan jika koefisiennya adalah 1 maka dianggap berkorelasi sempurna secara positif atau searah, yang artinya terdapat hubungan yang kuat secara searah antara dua atau lebih variabel yang di uji (Sugiyono, 2012).

\section{HASIL DAN PEMBAHASAN}

Penelitian ini dilakukan secara daring melalui laman web Google Form, dengan pranala https://bit.ly/kuesionermatanajwaujianreformasi. Berdasarkan hasil perhitungan Taro Yamane dengan tingkat kepercayaan 95\%, didapatkan responden sebanyak 400 orang dengan jenis kelamin laki-laki sebanyak 213 orang atau 53,3\% dan responden berjenis kelamin perempuan sebanyak 187 orang atau $46,7 \%$ dari jumlah keseluruhan. Selain itu, responden berusia 17-19 terdapat sebanyak 45 orang atau $11,3 \%$, usia 20 22 sebanyak 263 atau $65,8 \%$ dan usia 23-24 sebanyak 92 atau $23 \%$ dari total keseluruhan.

Dengan begitu, artinya sebagian besar responden yang mengisi kuesioner penelitian ini berumur 20-22 sedangkan usia responden 17-19 tahun menempati posisi paling rendah atau paling sedikit. Kemudian diketahui bahwa dari 400 responden yang telah mengisi kuesioner terdapat responden yang berstatus sebagai siswa sebanyak 29 orang atau $7,2 \%$, sebagai mahasiswa sebanyak 273 atau $68,3 \%$ dan sebagai pekerja sebanyak 98 orang atau $24,5 \%$ dari total jumlah keseluruhan. Dengan demikian, artinya responden yang mengisi kuesioner pada penelitian ini sebagian besar berstatus sebagai mahasiswa dan responden yang berstatus siswa mendapatkan posisi paling rendah atau paling sedikit.

Untuk bagian uji validitas, 9 dari 12 pernyataan variabel X1 (Terpaan), 18 dari 19 pernyataan variabel X2 (Kredibilitas) dan 13 dari 14 pernyataan variabel $\mathrm{Y}$ (Minat Berpolitik) dinyatakan valid dengan $r$ hitung $>r$ tabel $(0,361)$. Instrumen pernyataan variabel $\mathrm{X} 1$ yang dijadikan sebagai kuesioner dinyatakan reliabel 
dengan nilai Alpha Cronbach 0,823, Instrumen pernyataan variabel X2 yang dijadikan sebagai kuesioner dinyatakan reliabel dengan nilai Alpha Cronbach 0, 886. Begitu juga dengan variabel Y yang memiliki nilai Alpha Cronbach 0, 823.

Uji asumsi klasik yang terdiri dari uji normalitas, uji auto korelasi, uji multi-kolinieritas dan uji heteroskedastisitas diketahui bahwa uji normalitas mendapat nilai signifikansi pada tabel Kolmogrov Smirnov sebesar 0,080>0,05 dan data pada tabel P-Plot diketahui ploting (titiktitik) yang menggambarkan data sesungguhnya mengikuti garis sehingga dapat disimpulkan bahwa data yang di uji terdistribusi normal.

Untuk hasil nilai uji auto korelasi diketahui Berdasarkan tabel Durbin Watson 5\% (2;400) dan data pada tabel auto korelasi maka diketahui $1.7887<1.930<2,2113$ yang artinya tidak terdapat auto korelasi. Sedangkan untuk uji multikolinieritas diketahui nilai Toleransi yaitu $\mathrm{X} 1$ dan X2 yaitu 0,663 > 0,10 dan nilai VIF dari hasil uji multikolinieritas terpaan dan kredibilitas, yaitu $=1,507<10,00$ maka tidak terjadi multikolinieritas.

Kemudian untuk hasil uji heteroskedasitisitas peneliti melakukan dua uji yaitu uji Spearman Rho dengan nilai signifikansi variabel X1 sebesar $0.736>0.05$ dan nilai signifikansi variabel X2 sebesar $0.854>0.05$ yang membuktikan bahwa tidak terjadi heteroskedastisitas dan uji Scatterplot dengan hasil titik-titik data menyebar di atas dan di bawah atau di sekitar angka 0 , titik-titik data tidak mengumpul hanya di atas atau di bawah saja, penyebaran titik-titik data tidak membentuk pola bergelombang melebar kemudian menyempit dan melebar kembali, dan penyebaran titik-titik dan sebaliknya tidak berpola yang meyakinkan bahwa tidak terjadi heteroskedastisitas.

Berdasarkan hasil analisis regresi linier berganda, dapat diketahui bahwa peningkatan masing-masing variabel dapat meningkatkan pengaruh terhadap minat berpolitik generasi $\mathrm{Z}$, yakni dengan variabel X1 Terpaan yang nilainya sebesar 0,633 per satuan dan variabel X2 Kredibilitas Najwa Shihab sebesar 0,309 per satuan. Selain itu, diperoleh persamaan regresi sebagai berikut: $\mathrm{Y}=5,729+0,633 \mathrm{X} 1+0,309$ $\mathrm{X} 2$.

Untuk menguji kebenaran atau kelayakan dari analisis regresi, maka selanjutnya perlu dilakukan pengujian hubungan linieritas antara variabel X1 dan X2 terhadap variabel $\mathrm{Y}$. Uji hipotesis dilakukan dengan cara membandingkan besarnya angka taraf signifikasi ( $\mathrm{sig}$ ) penelitian dengan taraf signifikasi 0,05 yang mana jika angka signifikasi penelitian <0,05, maka Ho3 ditolak dan $\mathrm{Ha} 3$ diterima begitu pun sebaliknya. Berdasarkan hasil yang dapat diketahui nilai Sig atau angka Signifikasi penelitian adalah 0,000 yang berarti $0,000<0,05$, maka $\mathrm{Ho} 3$ ditolak dan Ha3 diterima. Ini menunjukkan bahwa Terpaan Video dan Kredibilitas Najwa Shihab mempengaruhi Minat Berpolitik Generasi Z.

Pada hasil yang didapati dengan uji $\mathrm{T}$ diketahui bahwa nilai t hitung untuk pengaruh Terpaan Video (X1) adalah $10.233>1.965$ atau lebih besar dari $\mathrm{T}$ tabel dan nilai Sig. $0.000<$ 0.05 lebih kecil dari taraf signifikasi 0,05. Maka Ho3 ditolak dan Ha1 diterima. Sehingga dapat disimpulkan bahwa Terpaan Video (X1) berpengaruh positif dan signifikan terhadap Minat Berpolitik (Y).

Sedangkan Kredibilitas (X2) terhadap Minat Berpolitik (Y) diketahui bahwa nilai $t$ hitung untuk Kredibilitas (X2) adalah 9.260 > 1.965 atau lebih besar dari nilai $\mathrm{T}$ tabel dan nilai Sig. $0.000<0.05$ lebih kecil dari taraf signifikasi 0,05. Maka Ho3 ditolak dan $\mathrm{Ha} 2$ diterima. Sehingga dapat disimpulkan bahwa Kredibilitas (X2) berpengaruh positif dan signifikan terhadap Minat Berpolitik (Y).

Pada uji $\mathrm{F}$ dapat disimpulkan bahwa nilai $\mathrm{F}$ hitung untuk yaitu Terpaan (X1) dan Kredibilitas (X2) terhadap Minat Berpolitik (Y) adalah $226.422>2.627$ atau lebih besar dari $\mathrm{F}$ tabel dan nilai Sig. $0.000<0.05$ lebih kecil dari 0,05. Maka Ha3 diterima dan Ho3 ditolak. Sehingga dapat disimpulkan bahwa Terpaan (X1) dan 
Kredibilitas (X2) berpengaruh positif dan signifikan terhadap Minat Berpolitik (Y).

Berdasarkan uji koefisien determinasi (r2), diketahui bahwa $0<0,657<1$ atau nilai $\mathrm{R}$ pada variabel X1 sebesar 0,657 dan berada di antara 0 dan 1. Artinya, hubungan Terpaan Video terhadap Minat Berpolitik Generasi Z dipengaruhi sebesar $0,657 \quad(65,7 \%)$ yang berdasarkan tabel interval dinyatakan Erat.

Sedangkan nilai $R$-square 0,432 berarti $43,2 \%$ nilai tersebut menunjukkan bahwa Terpaan Video memberikan dampak sebesar 43,2\% terhadap Minat Berpolitik Generasi Z, sedangkan sisanya $56,8 \% \quad(100 \%-43,2 \%)$ dijelaskan atau dipengaruhi oleh faktor lain di luar pada penelitian ini. Kemudian Adjusted $R$ Square sebesar 0,431 berarti $43,1 \%$ faktor Terpaan Video dapat dijelaskan oleh Minat Berpolitik. Sedangkan sisanya dapat dipengaruhi oleh faktor-faktor lain di luar penelitian ini lalu Standart Error of the Estimate artinya mengukur variasi dari nilai yang diprediksi. Standard Error of the Estimate pada variabel Terpaan Video adalah 3.73672. Semakin kecil standar deviasi berarti model semakin baik.

Berdasarkan uji koefisien determinasi (r2) juga, diketahui bahwa $0<0,640<1$ atau nilai $R$ pada variabel X2 sebesar 0,640 dan berada di antara 0 dan 1. Artinya, hubungan antar Kredibilitas Najwa Shihab terhadap Minat Berpolitik dipengaruhi sebesar 0,640 (64\%) yang berdasarkan tabel interval dinyatakan Erat. Sedangkan nilai R square 0,410 berarti $41 \%$ nilai tersebut menunjukkan bahwa Kredibilitas Najwa Shihab memberikan dampak sebesar $41 \%$ terhadap Minat Berpolitik sedangkan sisanya $59 \%(100 \%-41 \%)$ dijelaskan atau dipengaruhi oleh faktor lain di luar pada penelitian ini.

Kemudian Adjusted R-Square sebesar 0,408 berarti $40,8 \%$ faktor Kredibilitas Najwa Shihab dapat dijelaskan oleh Minat Berpolitik. Sedangkan sisanya dapat dipengaruhi oleh faktor - faktor lain di luar penelitian ini lalu Standard Error of the Estimate artinya mengukur variasi dari nilai yang diprediksi. Standard Error of the
Estimate adalah 3.80939. Semakin kecil standar deviasi berarti model semakin baik..

\section{Kesimpulan}

Hasil penelitian menunjukkan bahwa terpaan video Youtube Mata Najwa: Ujian Reformasi dan kredibilitas Najwa Shihab berpengaruh secara simultan dan parsial terhadap minat berpolitik generasi Z dalam isu RUU 2019. Dari dua variabel independen yang dianalisis, diperoleh hasil bahwa terpaan video Youtube Mata Najwa: Ujian Reformasi lebih besar mempengaruhi minat berpolitik generasi $\mathrm{Z}$ dalam isu RUU 2019. Hal ini dibuktikan dengan sebanyak $43,2 \%$ responden yang termasuk ke dalam generasi $\mathrm{Z}$ sepakat bahwa setelah mereka menonton video Youtube Mata Najwa: Ujian Reformasi yang membahas isu RUU 2019, tumbuh minat berpolitik di dalam diri mereka.

Berdasarkan uji koefisien determinasi diketahui pula bahwa hubungan antar terpaan video dan kredibilitas Najwa Shihab terhadap minat berpolitik mendapat nilai $\mathrm{R}$ sebesar 0,730 yang menurut tabel interval hubungan dinyatakan erat. Sedangkan pada uji hipotesis, penelitian ini bersifat positif karena terpaan video Youtube Mata Najwa: Ujian Reformasi (X1) dan kredibilitas Najwa Shihab (X2) berpengaruh secara simultan dan parsial terhadap minat berpolitik generasi Z dalam isu RUU 2019 (Y) sehingga dinyatakan bahwa Ho ditolak dan $\mathrm{Ha}$ diterima..

\section{References}

Abdul Rahman Shaleh dan Abdul Muhbib Wahab. (2004). Psikologi Suatu Pengantar Dalam Perspektif Islam. In Jakarta : Kencana.

Ardianto, E., \& Erdinaya, L. K. (2007). Komunikasi Massa: Suatu Pengantar (1st ed.). Bandung: Simbiosa Rekatama Media.

Hovland, C. I. (1953). Communication and Persuasion: Psychological Studies of Opinion Change, Volume 10. New York: Yale University Press. 
Katz, E., Blumler, J. G., \& Gurevitch, M. (1974). The uses of mass communication:Current Perspectives on Gratifications Research. In Sociology The Journal Of The British Sociological Association.

Kriyantono, R. (2016). Teknik Praktis Riset Komunikasi. Jakarta: Kencana Prenada Media Group.

McQuail, D. (2010). Mass Communication Theory (6th ed.). London: Sage Publication Ltd.

Rakhmat, J. (2012). Psikologi Komunikasi. Bandung: Remaja Rosda Karya.

Seemiller, C., \& Grace, M. (2017). Generation Z: Educating and Engaging the Next Generation of Students. About Campus:
Enriching the Student Learning Experience. https://doi.org/10.1002/abc.21293

Shaleh, A. R., \& Abdul, W. M. (2004). Psikologi Suatu Pengantar Dalam Prespektif Islam. Jakarta: Prenada Media.

Shihab, N. (2020). Ujian Reformasi (FULL VERSION).

Sugiyono. (2012). Metode Penelitian Kuantitatif, Kualitatif dan R \& D.Bandung:Alfabeta. Metode Penelitian Kuantitatif, Kualitatif Dan $R \&$ \& Dandung:Alfabeta. https://doi.org/10.1017/CBO978110741532 4.004

Suharsimi, A. (2006). Prosedur penelitian suatu pendekatan praktik. Jakarta: Rineka Cipta. 